\title{
Comparison and Prediction of the above Ground Carbon Storage in Croplands on the Inhabited Slopes on Mount Kilimanjaro (Tanzania) and the Taita Hills (Kenya)
}

\author{
Odeny Dickenss,2, Karanja Faith², Mwachala Geoffrey¹, Pellikka Petri' ${ }^{3,4}$, Marchant Rob ${ }^{5}$ \\ ${ }^{1}$ Center of Biodiversity, National Museums of Keny, Nairobi, Kenya \\ ${ }^{2}$ Department of Geospatial and Space Technology, The University of Nairobi, Nairobi, Kenya \\ ${ }^{3}$ Earth Change Observation Laboratory, Department of Geosciences and Geography, University of Helsinki, Helsinki, Finland \\ ${ }^{4}$ Helsinki Institute of Sustainability Science, University of Helsinki, Helsinki, Finland \\ ${ }^{5}$ York Institute for Tropical Ecosystems (KITE), Environment Department, University of York, York, UK \\ Email: d.odeny@gmail.com, dodeny@museums.or.ke
}

How to cite this paper: Dickens, O., Faith, K., Geoffrey, M., Petri, P. and Rob, M. (2018) Comparison and Prediction of the above Ground Carbon Storage in Croplands on the Inhabited Slopes on Mount Kilimanjaro (Tanzania) and the Taita Hills (Kenya). Journal of Geographic Information System, 10, 415-438.

https://doi.org/10.4236/jgis.2018.104022

Received: May 19, 2018

Accepted: August 14, 2018

Published: August 17, 2018

Copyright (c) 2018 by authors and Scientific Research Publishing Inc. This work is licensed under the Creative Commons Attribution International License (CC BY 4.0).

http://creativecommons.org/licenses/by/4.0/

\begin{abstract}
Mount Kilimanjaro and the Taita Hills are adjacent montane areas that experience similar climate and agricultural activity, but which differ in their geologic history, nature of elevation gradients and cultures. We assessed differences in cropland above ground carbon (AGC) between the two sites and against environmental variables. One hectare sampling plots were randomly distributed along elevational gradients stratified by cropland type; AGC was derived from all trees with diameter $\geq 10 \mathrm{~cm}$ at breast height in each plot. Predictor variables were physical and edaphic variables and human population. A generalized linear model was used for predicting AGC with AIC used for ranking models. AGC was spatially upscaled in $2 \mathrm{~km}$ buffer and visually compared. Kilimanjaro has higher AGC in cropped and agroforestry areas than the Taita Hills, but only significant difference in AGC variation in agroforestry areas $(\mathrm{F}=9.36, \mathrm{p}=0.03)$. AGC in cropped land and agroforestry in Kilimanjaro has significant difference on mean $(t=4.62, p=0.001)$ and variation $(\mathrm{F}=17.41, \mathrm{p}=0.007)$. In the Taita Hills, significant difference is observed only on the mean AGC $(t=4.86, p=0.001)$. Common tree species that contribute the most to AGC in Kilimanjaro are Albizia gummifera and Persea americana, and in the Taita Hills Grevillea robusta and Mangifera indica. Significant and univariate predictors of AGC in Mount Kilimanjaro are $\mathrm{pH}\left(\mathrm{R}^{2}=\right.$ $0.80, p=0.00)$ and EVI $\left(R^{2}=0.68, p=0.00\right)$. On Mount Kilimanjaro, the top multivariate model contained SOC, CEC, $\mathrm{pH}$ and BLD $\left(\mathrm{R}^{2}=0.90, \mathrm{p}=0.00\right)$,
\end{abstract}


whereas in the Taita Hills, the top multivariate model contained elevation, slope and population $\left(\mathrm{R}^{2}=0.89, \mathrm{p}=0.00\right)$. Despite of the difference in land management history of Mount Kilimanjaro and the Taita Hills, mean of AGC in croplands does not differ significantly. Difference occurs on variation of AGC, type of trees contributing AGC, and environmental variables that explain AGC distribution. The research results provide reference for management of carbon sequestration on inhabited montane areas.

\section{Keywords}

Aboveground Carbon, Cropland, Agroforestry, Cropped Land, Elevation Gradient

\section{Introduction}

Cropland is a broad land-use category and can be divided into three types based on the land management: rice paddies, cropped land and agroforestry systems [1]. The latter is characterised by crops and/or livestock combined with shrubs and trees, but with the density of trees falling below the threshold used for the Intergovernmental Panel on Climate Change (IPCC) Forest Land category [2]. The amount of carbon lost when forest or woodland is converted to cropped land varies considerably between the agroforestry and cropped land systems. About $40-$ $180 \mathrm{Mg} \mathrm{C} \mathrm{ha}^{-1}$ aboveground carbon and $10 \mathrm{Mg} \mathrm{C} \mathrm{ha}^{-1}$ topsoil are lost when forest is converted agroforestry, in comparison to an estimated $80-400 \mathrm{Mg} \mathrm{C} \mathrm{ha}^{-1}$ and $25 \mathrm{Mg} \mathrm{C} \mathrm{ha}^{-1}$ respectively under conversion to continuous cropping [2]. Areas converted into agroforestry can be more productive than treeless alternatives and continue to provide environmental benefits for land users at all levels [3] [4].

Croplands in montane areas are part of forest or woodland that was converted by expanding agricultural communities. The conversion of forest, woodland or shrubland into cropland adversely affects the productivity of vegetation [5] and this is associated with the tree species and amount of carbon loss on the landscape. Some indigenous trees are often left and exotic trees are planted for food production and timber on cropland [6] [7] [8]. These areas, however, form important part of an agro-ecosystem that supports biodiversity and carbon sequestration [9].

The rate of cropland expansion in the horn of Africa has in the recent years decreased from 2.3\% between the period of 1975 and 2000 [10] to $1.4 \%$ between 1990 and 2010 [11] [7]. Cropland cover area in East Africa has shown variation in estimation ranging from $1.8 \%$ [12] in some areas, $12.5 \%$ [13] and $22.7 \%$ in other areas according to Global Land Cover 2000 [14] in the late 1990s/early 2000s [15]. Around Mount Kilimanjaro croplands constitute over $50 \%$ of the land [16] and this is projected to cover $60 \%$ of the area by 2030 [17]. The lowlands and foothills of mountains experience expansion of croplands at the expense of thickets and shrublands [18]. The expansion of croplands is associated 
with high human population growth [19] that exerts pressure on land due to increased demand for food.

Croplands in tropical Africa store about $5.3 \mathrm{Mg} \mathrm{C} \mathrm{ha}^{-1}$ and the mosaic forest/cropland has $91.5 \mathrm{Mg} \mathrm{C}^{-1}$ [20]. In East Africa, the median range for carbon storage in cropland is estimated between $1.6-4.8 \mathrm{Mg} \mathrm{C} \mathrm{ha}^{-1}$ [21]. Existing literature that covers carbon standing stock and carbon soil in croplands [22] depends on large spatial scale studies that do not provide comprehensive and reliable information on local carbon storage in the sub-montane and montane areas in East Africa. Moreover, carbon storage in montane forests has been given more attention than the adjacent cropland. Carbon storage in the croplands of the Taita Hills occurs between 2.3 to $9.1 \mathrm{Mg} \mathrm{C} \mathrm{ha}^{-1}$ [7]. In Kilimanjaro (Mwanga area) areas with high aboveground carbon storage occur in agroforestry areas which has an estimated average amount of $19.4 \mathrm{Mg} \mathrm{C}^{-1}$ (between 10.7 to $57.1 \mathrm{Mg} \mathrm{C} \mathrm{ha}^{-1}$ ) [23].

Most studies on carbon storage are based on a particular biome (woodland and forests) and rarely look at cropland along an elevation gradient in mountainous areas. Elevation gradients play an important role in influencing climate; for instance, the highlands influences rainfall and temperature regime [24] that ultimately influences the distribution of vegetation [25]. Montane areas with shorter elevation gradients are characterized by compressed vegetation zonation and appearance of cloud montane forests in lower elevations [26] [27]. Soil texture discontinuity and micro-climate variation are influenced by short elevation gradients than longer gradients [27]. Besides this, the human population plays important role in determining the distribution of plant species and carbon storage [19]. A recent study by Adhikari et al. [28] showed that carbon stocks are highest on steep eastern and southern slopes of the Taita Hills, which are too laborious for agricultural practices, and thus remained in natural condition.

Kilimanjaro and the Taita Hills are located $100 \mathrm{~km}$ apart with similar climate characteristics although they have a very different geology; the Taita Hills are ancient crystalline mountains and Kilimanjaro is a more recent volcanic mountain. This geological difference impacts on the nature of soils and biodiversity in the areas [29]. The Taita Hills are the northern-most part of the Eastern Arc Mountain chain that is characterized by significant numbers of endemic species of plants and animals [29]. Both mountain areas are characterized by high human population growth and expanding small-scale agriculture which potentially affects carbon storage in croplands on the inhabited slopes. With the current and growing demand for balancing carbon storage, sustainable livelihoods and conservation of biodiversity, there is need to increase aboveground carbon sequestration in croplands [2].

The aim of this study was to assess the aboveground carbon and how its distribution is influenced by environmental variables on croplands on the inhabited slopes of Mount Kilimanjaro and the Taita Hills. The specific research questions were: 1 ) is there a difference in carbon storage between sites and different types 
of croplands? 2) which species contribute more AGC on the inhabited slopes of Mount Kilimanjaro and the Taita Hills? and 3) which environmental variables best explain the distribution of AGC along the elevation gradients?

\section{Methodology}

\subsection{Study Area}

\subsubsection{The Taita Hills}

The Taita Hills are located in southern Kenya, approximately $300 \mathrm{~km}$ southeast of Nairobi (Figure 1). The highest point in the Taita Hills is Vuria at $2208 \mathrm{~m}$ a.s.l. The area experiences two rainy seasons a year: long rains fall from March to May and short rains from October to December. Annual is in the range 1100 and $1400 \mathrm{~mm} \mathrm{yr}^{-1}$, increasing with altitude and on wetter, eastern aspects, compared with $500 \mathrm{~mm} \mathrm{yr}^{-1}$ in the surrounding plains [30]. The mean temperature varies from $21^{\circ} \mathrm{C}$ in August to $26^{\circ} \mathrm{C}$ in February, compared with $23^{\circ} \mathrm{C}-27^{\circ} \mathrm{C}$ in the plains [31]. The study transect is located in the wetter south-eastern and southern parts of the Taita Hills.

The Taita Hills can be distinguished by three agro-ecological zones based on

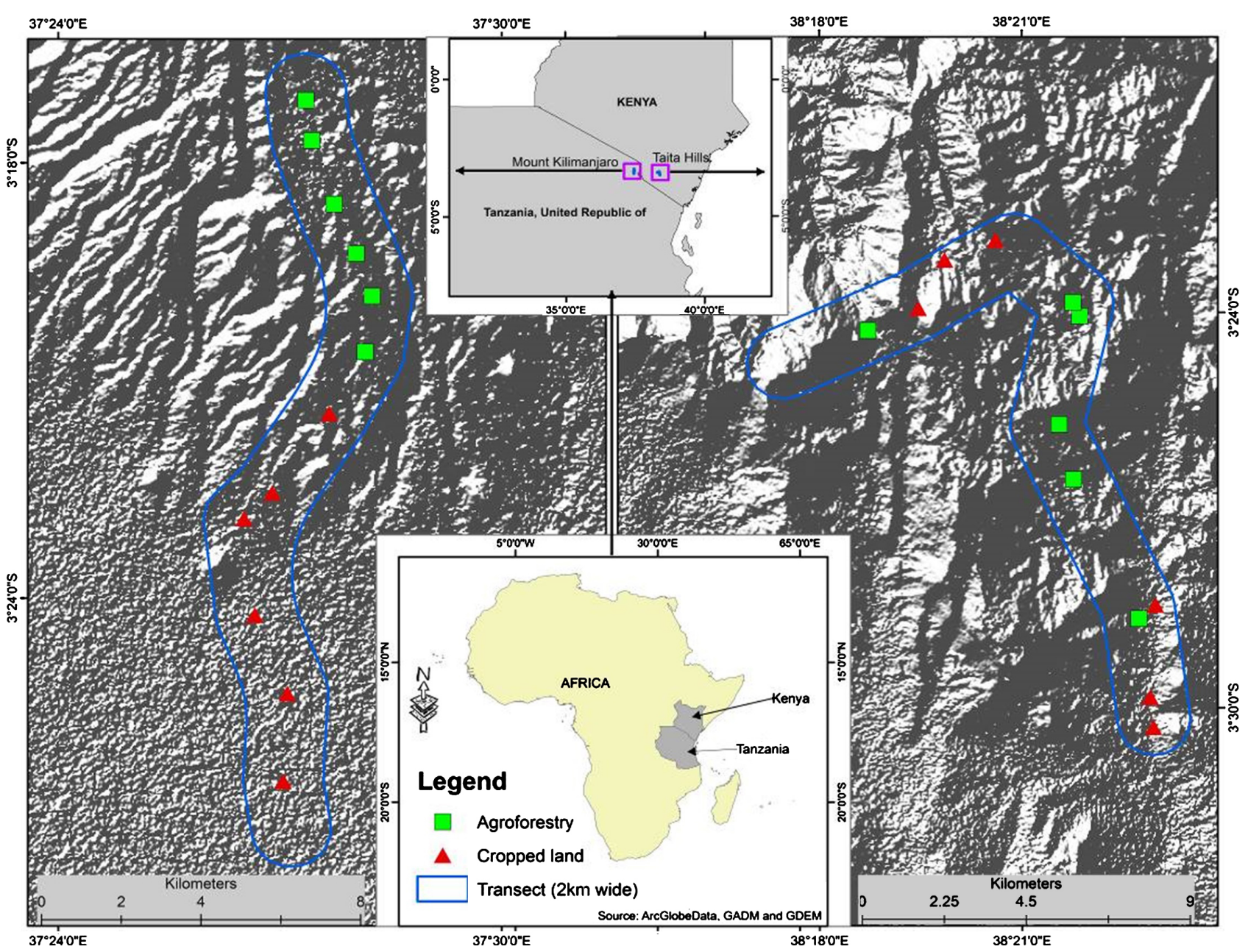

Figure 1. Transect and plot locations on Mount Kilimanjaro (left) and the Taita Hills (right). 
the crop-suitability of soils and climate: Lower Highland (LH) - maize, peas, potatoes, cabbages, cauliflower, kales, carrots, beetroot, spinach, lettuce, plums, passion fruit; Lower Midland (LM)—maize, sorghum, millet, sunflower, beans (tepary), cowpeas, black and green grams, chicken peas, pumpkin; Upper Midland zones (UM) - coffee, avocado, onions, cabbages, macadamia nuts, castor, bananas, pawpaws, citrus, sunflower and maize [32].

The three main forest types in the Taita Hills are indigenous montane forests, plantation forests of Eucalyptus spp., Pinus spp. and Cypressus lusitanica, and woodlands consisting of both native and exotic species [32]. The total area of indigenous forest remaining is approximately $8 \mathrm{~km}^{2}$, plantation forests cover $26 \mathrm{~km}^{2}$, woodlands $64 \mathrm{~km}^{2}$, and cropland $375 \mathrm{~km}^{2}$ [7]. Of the cropped areas, $70 \%$ is continuous cropland (little tree cover), and 30\% is agroforestry [7], in which typical species are exotic Grevillea robusta, Mangifera indica, Persea americana, and native species such as Prunus africana [6].

\subsubsection{Mount Kilimanjaro}

Mount Kilimanjaro is located in north-eastern Tanzania, approximately $300 \mathrm{~km}$ south from Nairobi (Figure 1). Annual rainfall varies with altitude; about 1200 to $2000 \mathrm{~mm} \mathrm{yr}^{-1}$ is received in the highland area; 1000 to $1200 \mathrm{~mm} \mathrm{yr}^{-1}$ in the midlands and 400 to $900 \mathrm{~mm} \mathrm{yr}^{-1}$ in the lowlands. The montane zone, which is dominated by agroforestry systems above $1800 \mathrm{~m}$, receives the highest rainfall. Due to the fertile volcanic soils and favourable climate the area is densely settled and supports agriculture. Similarly, as in the Taita Hills, the eastern and southern parts receive more rainfall. Mount Kilimanjaro has three distinct agro-ecological zones: the highland zone occurring between 1200 and $1800 \mathrm{~m}$ characterized predominantly coffee-banana belt; the midland area, occurring between 900 and $1200 \mathrm{~m}$, is predominantly a maize-bean belt, and; the lowlands that extend 700 to $900 \mathrm{~m} \mathrm{[33].} \mathrm{A} \mathrm{half-mile} \mathrm{narrow} \mathrm{forest} \mathrm{strip} \mathrm{occurs} \mathrm{above} \mathrm{the} \mathrm{coffee-banana}$ belt, which was established in 1941 as a buffer forest along the lower edge of the montane forest to provide local people with timber and non-timber forest products, preventing incursion into the National Park [33].

The study is conducted along two transects encompassing a wide range of environmental, land use and social conditions. On both Mount Kilimanjaro and Taita Hills, the study transects are located on wetter, eastern aspects (Figure 1).

\subsection{Methods}

\subsubsection{Sampling Plots}

The primary data collection and analytical framework is presented in a flow diagram. A standard size plot of 1 ha [34] was used for sampling biometric parameters for trees with diameter at breast height $(\mathrm{dbh}) \geq 10 \mathrm{~cm}$. Stratified random sampling was used to partition the study area into agroforestry and cropped lands. However, the distribution of plots in agroforestry areas and cropped land were random along the elevation gradients of Mount Kilimanjaro and the Taita Hills. Within these stratifications, plots were distributed randomly using simple 
random sampling; six plots were distributed in agroforestry areas and another six in cropped lands. These plots were located within the $1 \mathrm{~km}$ buffer (either side) of the study transect that runs along the elevation gradients on Kilimanjaro and the Taita Hills both having transect length of $20 \mathrm{~km}$. In the Taita Hills the transect runs from Mwatate at $840 \mathrm{~m}$ to Vuria at an elevation of $1900 \mathrm{~m}$ (Figure 1). In Kilimanjaro the transect runs from Miwaleni at $730 \mathrm{~m}$ through Kawawa to Kirua-Vunjo at an elevation of $1800 \mathrm{~m}$, near the boundary of the National Park (TANAPA). For each tree, DBH was measured at $1.3 \mathrm{~m}$, and tree height was measured using a hypsometer. Tree species were identified with the assistance of botanists from the National Museums of Kenya.

\subsubsection{Estimation of Plot Carbon}

The Above-Ground Biomass (AGB) was estimated using the $\mathrm{DBH}$ and tree height recorded and the Wood Specific Gravity (WSG) $\left(\mathrm{g} / \mathrm{cm}^{3}\right)$ derived from the Global Wood Density Database [35] [36] for the tree species; either at species level or genus, or family depending on the available information. With these parameters, an allometric model [37] was used for estimating AGB.

$$
\mathrm{AGB}=0.0673 \times\left(\rho \times D^{2} H\right)^{0.976}
$$

Where $\rho$ is the Wood Specific Gravity, $D^{2}$ is the dbh, and $H$ is the height of the tree. According to [37], the above model performed well across forest types and bioclimatic conditions. After deriving the AGB for each tree, data was aggregated to plot level from which $50 \%$ of AGB was assumed to be the above-ground carbon storage in a plot [37] [38] [39]. The standard unit for the amount of the above-ground carbon in this study is expressed in Megagram Carbon per hectare $\left(\mathrm{Mg} \mathrm{Cha}^{-1}\right)$.

\subsubsection{Environmental Variables}

To understand the relationships between environment, soil, vegetation and AGC a series of soil and biophysical variables were used as predictor variables to explain the patterns of AGC stored across the altitudinal gradient, and within the major land-uses. Biophysical variables used were Enhanced Vegetation Indices (EVI) from the Moderate Resolution Imaging Spectroradiometer (MODIS) 16-days interval for the year 2012 downloaded from the National Aeronautics and Space Administration (NASA) Earth Observing System Data and Information System (Table 1) for both Kilimanjaro and the Taita Hills. The mean for the 16-days interval for the year was used for analysis. MODIS-EVI was chosen because EVI minimizes canopy background variations and maintains sensitivity over dense vegetation conditions [40]. MODIS-EVI layers were downloaded in October 2014. The major land-use was acquired from field observation between May and August 2012.

Based on studies that were previously conducted on environmental controls over the aboveground biomass [41] [42], physical and soil variables were selected. Physical variable consisted of elevation (digital elevation model, DEM 
Table 1. The environmental variables abbreviated and described of their units of measurement, spatial resolution and their sources.

\begin{tabular}{|c|c|c|c|c|c|}
\hline Environmental factors & Variable & Abbr. & Unit of Measurement & Spatial Resolution & Source of data \\
\hline Edaphic factors & Soil organic carbon & SOC & $\mathrm{C} /$ permilles & $930 \mathrm{~m}$ & isric.org \\
\hline $\begin{array}{l}\text { six layers mean estimate } \\
\text { for depths; }\end{array}$ & Cation exchange capacity & CEC & $\mathrm{cmolc} / \mathrm{kg}$ & $930 \mathrm{~m}$ & isric.org \\
\hline \multirow{2}{*}{$\begin{array}{l}2.5,10,22.5,45,80 \text {, and } \\
150 \mathrm{~cm} \text { depths }\end{array}$} & $\mathrm{pH}$ & $\mathrm{pH}$ & & & isric.org \\
\hline & Bulk density & BLD & $\mathrm{kg} / \mathrm{m}^{3}$ & $930 \mathrm{~m}$ & isric.org \\
\hline \multirow[t]{3}{*}{ Physical factor } & Elevation & Elev & meter & $30 \mathrm{~m}$ & Geonetwork portal \\
\hline & Slope angle & Slope & Degree & $30 \mathrm{~m}$ & Derived from elevation \\
\hline & $\begin{array}{c}\text { Enhanced vegetation } \\
\text { index MODIS-EVI } 16 \text { days } \\
\text { interval }\end{array}$ & EVI & $0-1$ index & $659 \mathrm{~m}$ & NASA \\
\hline \multirow[t]{2}{*}{ Human population } & Population density & PopDen & Person $/ \mathrm{km}^{2}$ & $1 \mathrm{~km}$ & \\
\hline & Cropped land & \multicolumn{4}{|c|}{ These are areas predominated by mono-cropping system and sparsely populated } \\
\hline Cropland & Agroforestry & \multicolumn{4}{|c|}{$\begin{array}{l}\text { These are areas with fruit trees, and other trees; mixed crops both cash and food crops; } \\
\text { moderate to densely populated }\end{array}$} \\
\hline
\end{tabular}

$30 \mathrm{~m}$ ) and slope; the latter was derived from DEM. Four edaphic variables were selected and downloaded from ISRIC (SoilGrids $1 \mathrm{~km}$ ) for the analysis; these included the cation exchange capacity (CEC), soil $\mathrm{pH}$, soil organic carbon (SOC) and soil bulk density (BLD) (Table 1).

\subsubsection{Data Extraction and Statistical Modelling}

Point values were extracted from the environmental variable layers using point analyses tool in ArcGIS 10. These were aggregated under major land use systems for Kilimanjaro and the Taita Hills for statistical analysis using the R programme [43]. Data relationships were described using univariate statistics and portrayed as series of boxplots to describe the amount of variation in agroforestry and cropped land in Kilimanjaro and the Taita Hills. Fischer's F-test (var test) was used to test the significance of the variation of data, and Student's t-test ( $t$ test) was used to test the significance difference in the data means between agroforestry and cropped land within sites; agroforestry, and cropped land between sites. Standard error of mean of AGC was calculated with R programme for the sites and different types of cropland. A Generalized Linear Model (GLM) was used to assess the relationships of AGC with the environmental variables. Where data points were non-linear, 2nd or 3rd order of polynomials were used to fit the model relation. Akaike Information Criterion (AIC) scores were used to rank the model relationship by sites and explain the distribution of AGC and various land-uses. AGC was upscaled for visualization of distribution along the Kilimanjaro and the Taita Hills transects using the GLM function in R and extrapolation in ArcGIS on the surface of environmental variables. Spatial map visualization of variables was performed using ArcGIS 10.2. 


\section{Results}

\subsection{Aboveground Carbon on Sites}

The mean Aboveground Carbon (AGC) along the Kilimanjaro transect is 39.06 $\pm 6.48 \mathrm{Mg} \mathrm{C} \mathrm{ha}^{-1}$ (mean $\pm \mathrm{SE}$ ) and along the Taita Hills transect the mean is 28.82 $\pm 5.82 \mathrm{Mg} \mathrm{C} \mathrm{ha}^{-1}$; both areas having comparable variation and means (Table 2). The mean of AGC in cropped land in Kilimanjaro is $19.67 \pm 5.18 \mathrm{Mg} \mathrm{C} \mathrm{ha}^{-1}$ which is a third of the mean AGC in agroforestry $58.45 \pm 2.75 \mathrm{Mg} \mathrm{C} \mathrm{ha}^{-1}$. Significant difference in variation, and the mean were observed on AGC between agroforestry and cropped land in Kilimanjaro $(\mathrm{F}=17.41, \mathrm{p}=0.007)$, and $(\mathrm{t}=4.62, \mathrm{p}=$ 0.001 ) respectively (Table 2 ).

Distribution of AGC is in agroforestry area in Kilimanjaro has median tends towards the 1st quartile 52.95. In cropped land, the median tends slightly towards the 3rd quartile (30.43) (Figure 2). The mean of AGC in cropped land in the Taita Hills is $13.69 \pm 1.54 \mathrm{Mg} \mathrm{C} \mathrm{ha}^{-1}$; less than a third of the mean AGC in agroforestry $43.95 \pm 7.4 \mathrm{Mg} \mathrm{C} \mathrm{ha}^{-1}$. In agroforestry area, the median tends towards the 1st quartile 52.95 but in cropped land, the median tends slightly towards the 3rd quartile (30.43) (Figure 2). The variation of AGC in cropped land and agroforestry in the Taita Hills does not differ significantly; however, their means are significantly different $(\mathrm{t}=4.86, \mathrm{p}=0.001)$ (Figure 2 and Figure 3 , Table 2). Thus, the mean of AGC in agroforestry from the Kilimanjaro is $30 \%$

Table 2. The univariate statistics (mean and standard error), Fischer's and Student's t test for AGC distribution in cropped land and agroforestry areas in Kilimanjaro and the Taita Hills.

\begin{tabular}{|c|c|c|c|c|c|c|c|}
\hline \multirow{2}{*}{\multicolumn{2}{|c|}{ Comparison }} & \multicolumn{2}{|c|}{ Mean \pm SE } & \multicolumn{2}{|c|}{ Fischer's F test } & \multicolumn{2}{|c|}{ Student's t test } \\
\hline & & Kilimanjaro & Taita & $\mathrm{F}$ & $\mathrm{p}$ & $\mathrm{t}$ & $\mathrm{p}$ \\
\hline \multirow{2}{*}{ Between sites } & Agroforestry & $58.45 \pm 2.75$ & $43.95 \pm 7.4$ & 9.36 & 0.03 & 1.95 & 0.08 \\
\hline & Cropped land & $19.67 \pm 5.18$ & $13.69 \pm 1.54$ & 10.92 & 0.02 & 0.58 & 0.57 \\
\hline \multirow{2}{*}{ Within site } & \multicolumn{2}{|c|}{ Cropped land vs } & Kilimanjaro & 17.41 & 0.01 & 4.62 & 0.00 \\
\hline & \multicolumn{2}{|c|}{ Agroforestry AGC } & Taita & 5.87 & 0.08 & 4.86 & 0.00 \\
\hline
\end{tabular}

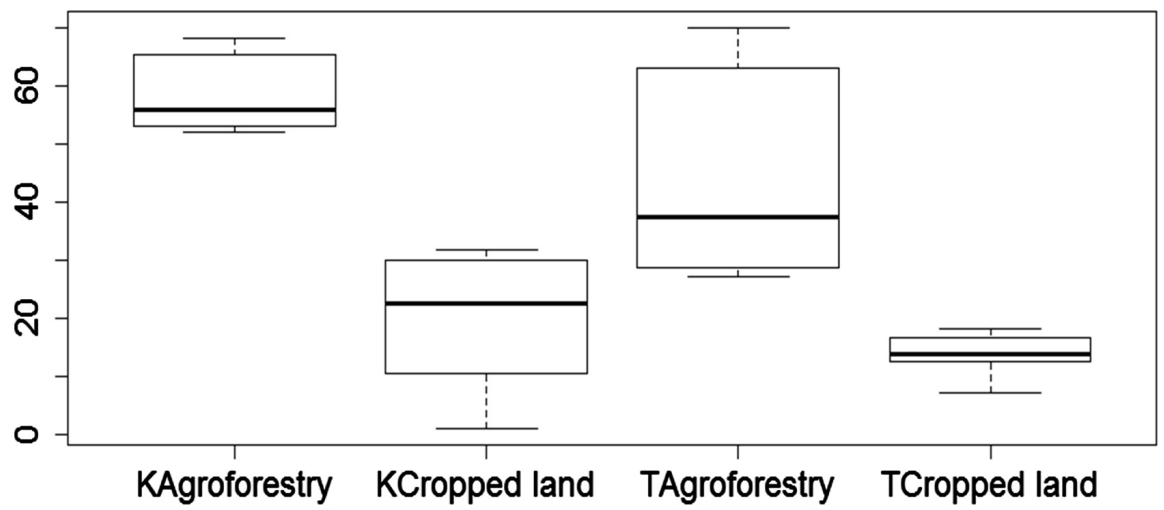

Figure 2. AGC (Mg C/ha) boxplot for cropped land and agroforestry areas in Kilimanjaro (prefix K) and Taita Hills (prefix T). 
greater that of Taita Hills. This shows significant difference in variation $(\mathrm{F}=$ 9.36, $\mathrm{p}=0.028$ ) but their means are not significantly different (Figure 2, Figure 3 , Table 2). The variation of AGC in the cropped lands in the two sites are significantly different $(\mathrm{F}=10.92, \mathrm{p}=0.020)$ while their means is not significantly different (Figure 2, Table 2). The mean and median of AGC data in agroforestry areas in the Taita Hills are very close $31.98 \pm 7.40 \mathrm{Mg} \mathrm{C} \mathrm{ha}^{-1}$ (median 32.56). The boxplot indicate plots with small and large amount of AGC in agroforestry are heterogeneous but plots with moderate amount of AGC are homogeneous along the elevation gradient (Figure 2, Table 2).

Most of the AGC data in cropped land are distributed towards the 1st quartile (13.24); thus, the mean (22.43 \pm 5.49$)$ and median (15.62) of AGC are not close. However, variation of AGC data for cropped lands in the Taita Hills is both below the 1st and 3rd quartiles (Figure 2, Table 2). The AGC in agroforestry on Kilimanjaro area is more than agroforestry in the Taita Hills; Tukey's pairwise comparisons shows the two sites are significantly different in the amount of AGC (Table 2). No significant difference is observed in the amount of AGC in cropped lands on Kilimanjaro and the Taita Hills.

\subsection{AGC vs Environmental Variables in Types of Cropland}

The response of AGC with EVI in agroforestry in Kilimanjaro is very significant and the relationship is fitted by the 2 nd order of polynomial $\left(R^{2}=0.92, p=\right.$ 0.020) (Figure 3, Table 3). The relationship of AGC and CEC in agroforestry in Kilimanjaro is significant and the relationship is fitted by the 2nd order of polynomial $\left(\mathrm{R}^{2}=0.91, \mathrm{p}=0.027\right)$ (Figure 3, Table 3). The response of AGC with BLD in agroforestry in Kilimanjaro shows significant relationship $\left(\mathrm{R}^{2}=0.87, \mathrm{p}=\right.$ 0.045 ), fitted by the 2 nd order of polynomial (Figure 3, Table 3 ). The relationship between AGC in agroforestry from the Taita Hills with the above variables are strong but are not significantly related (Figure 3, Table 3). The response of AGC to EVI, CEC and BLD in cropped lands on Kilimanjaro and the Taita Hills are weak and does not show significant relationships (Figure 3, Table 3).

The relationship of AGC and $\mathrm{pH}$ in agroforestry in the Taita Hills is very strong and significant $\left(R^{2}=0.98, p=0.031\right)$, fitted by the 3 rd order of polynomial (Figure 3, Table 3). A significant relationship occurs between AGC and SOC in cropped land in the Taita Hills $\left(R^{2}=0.70, p=0.00\right)$, fitted by 1st order of polynomial. On the other side, the relationship of SOC and AGC in cropped land on Kilimanjaro is weak and not significant (Figure 3, Table 3).

\subsection{AGC vs Woody Plant Species along Elevation Gradients}

The distribution of the AGC among the woody plant species on the slope of Mount Kilimanjaro is predominated by Albizia gummifera with carbon storage of $8.6 \mathrm{MgC} / \mathrm{ha}$; this is followed by Persea americana (3.5 MgC/ha) and Ficus sycomorus (3.3 MgC/ha) (Figure 4(a)). In the Taita Hills, the predominant woody species is Grevillea robusta with AGC of $4.6 \mathrm{MgC} / \mathrm{ha}$; followed by Mangifera 


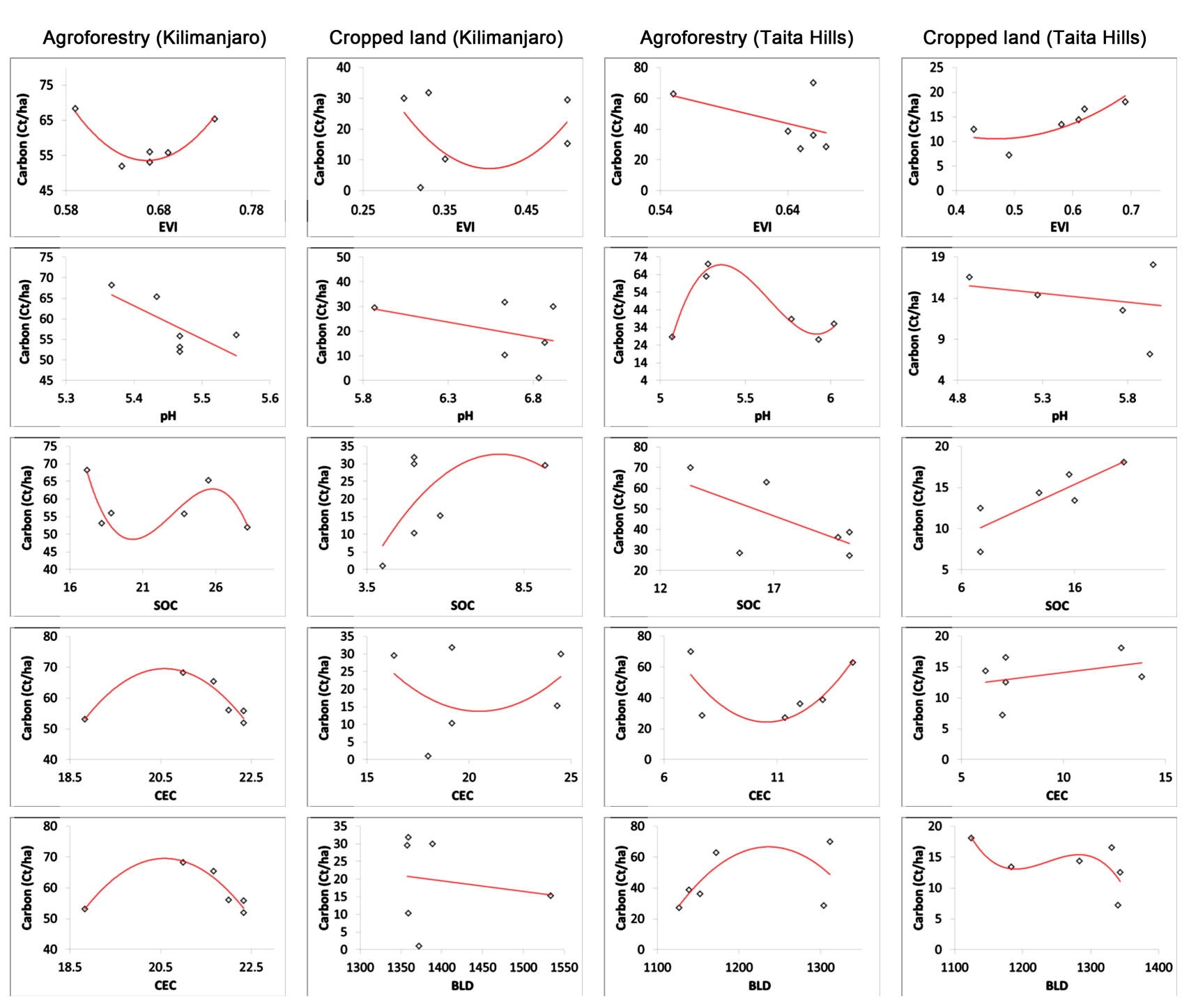

Figure 3. Linear and polynomial (2nd and 3rd) fitted models for relationships of AGC with environmental variables in agroforestry and cropped land in Kilimanjaro and the Taita Hills.

Table 3. Model relationships of AGC with environmental variables in agroforestry and cropped land in Kilimanjaro and the Taita Hills.

\begin{tabular}{|c|c|c|c|c|c|c|c|c|c|}
\hline \multirow{2}{*}{ Environmental Variable } & \multirow{2}{*}{ Cropland } & \multicolumn{4}{|c|}{ Kilimanjaro } & \multicolumn{4}{|c|}{ Taita } \\
\hline & & Fit. Order & $\mathbf{R}^{2}$ & $\mathrm{p}$ & AIC & Fit. Order & $\mathbf{R}^{2}$ & $\mathrm{p}$ & AIC \\
\hline \multirow{2}{*}{ EVI } & Agroforestry & $x^{2}$ & 0.92 & 0.020 & 31 & $x^{2}$ & 0.26 & 0.639 & 57 \\
\hline & Cropped land & $x^{2}$ & 0.14 & 0.805 & 54 & $x^{2}$ & 0.72 & 0.152 & 32 \\
\hline \multirow{2}{*}{$\mathrm{pH}$} & Agroforestry & $x$ & 0.50 & 0.115 & 41 & $x^{3}$ & 0.98 & 0.031 & 38 \\
\hline & Cropped land & $x$ & 0.14 & 0.458 & 52 & $x$ & 0.10 & 0.540 & 37 \\
\hline \multirow{2}{*}{$\mathrm{SOC}$} & Agroforestry & $x^{3}$ & 0.81 & 0.272 & 39 & $x$ & 0.43 & 0.160 & 53 \\
\hline & Cropped land & $x^{2}$ & 0.36 & 0.507 & 52 & $x$ & 0.70 & 0.038 & 31 \\
\hline \multirow{2}{*}{ CEC } & Agroforestry & $x^{2}$ & 0.91 & 0.027 & 32 & $x^{2}$ & 0.64 & 0.213 & 53 \\
\hline & Cropped land & $x^{2}$ & 0.12 & 0.820 & 54 & $x$ & 0.14 & 0.474 & 37 \\
\hline \multirow{2}{*}{ BLD } & Agroforestry & $x^{2}$ & 0.87 & 0.045 & 35 & $x^{2}$ & 0.29 & 0.599 & 57 \\
\hline & Cropped land & $\mathrm{x}$ & 0.03 & 0.760 & 52 & $x^{3}$ & 0.50 & 0.652 & 38 \\
\hline
\end{tabular}




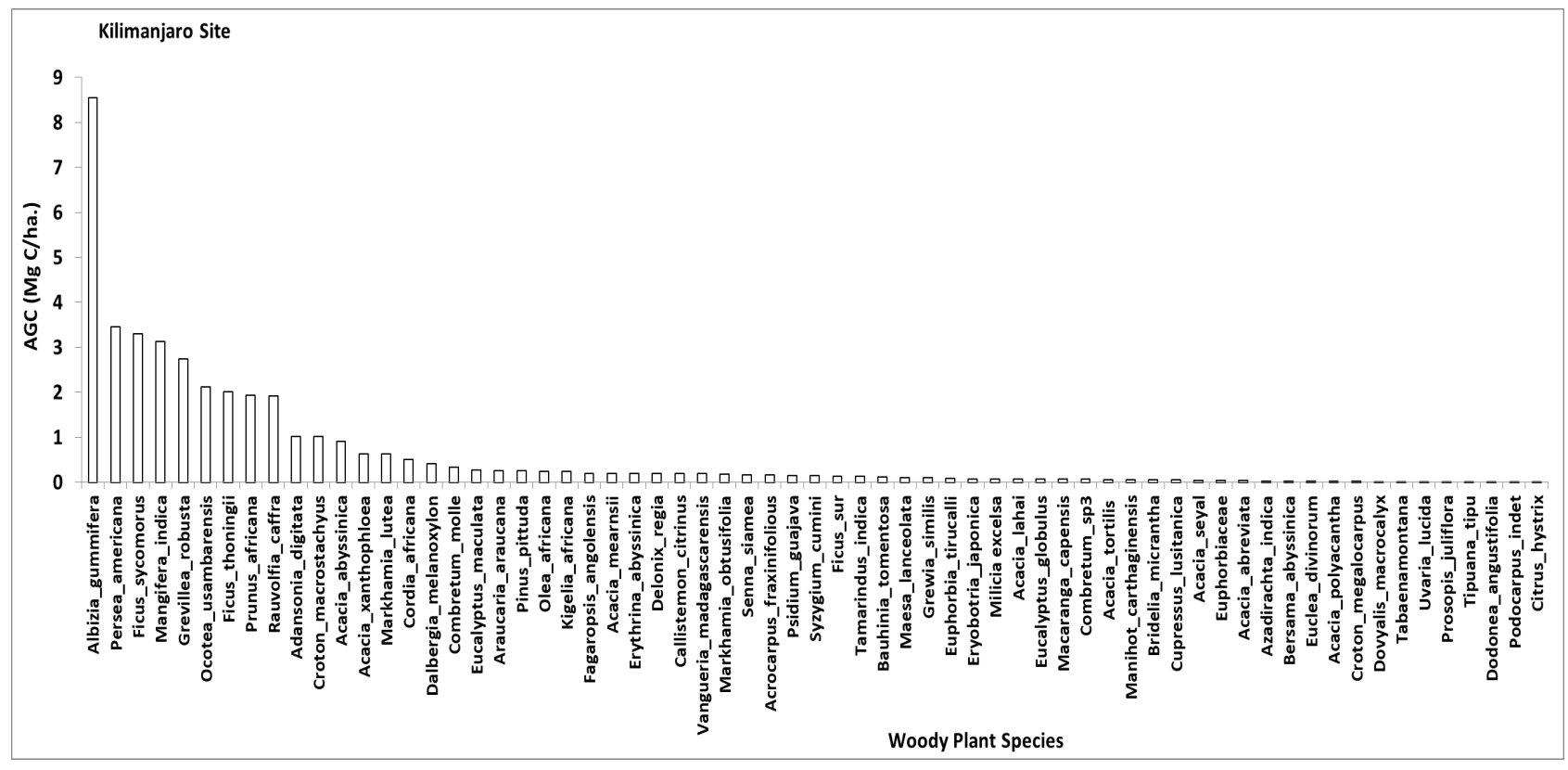

(a)

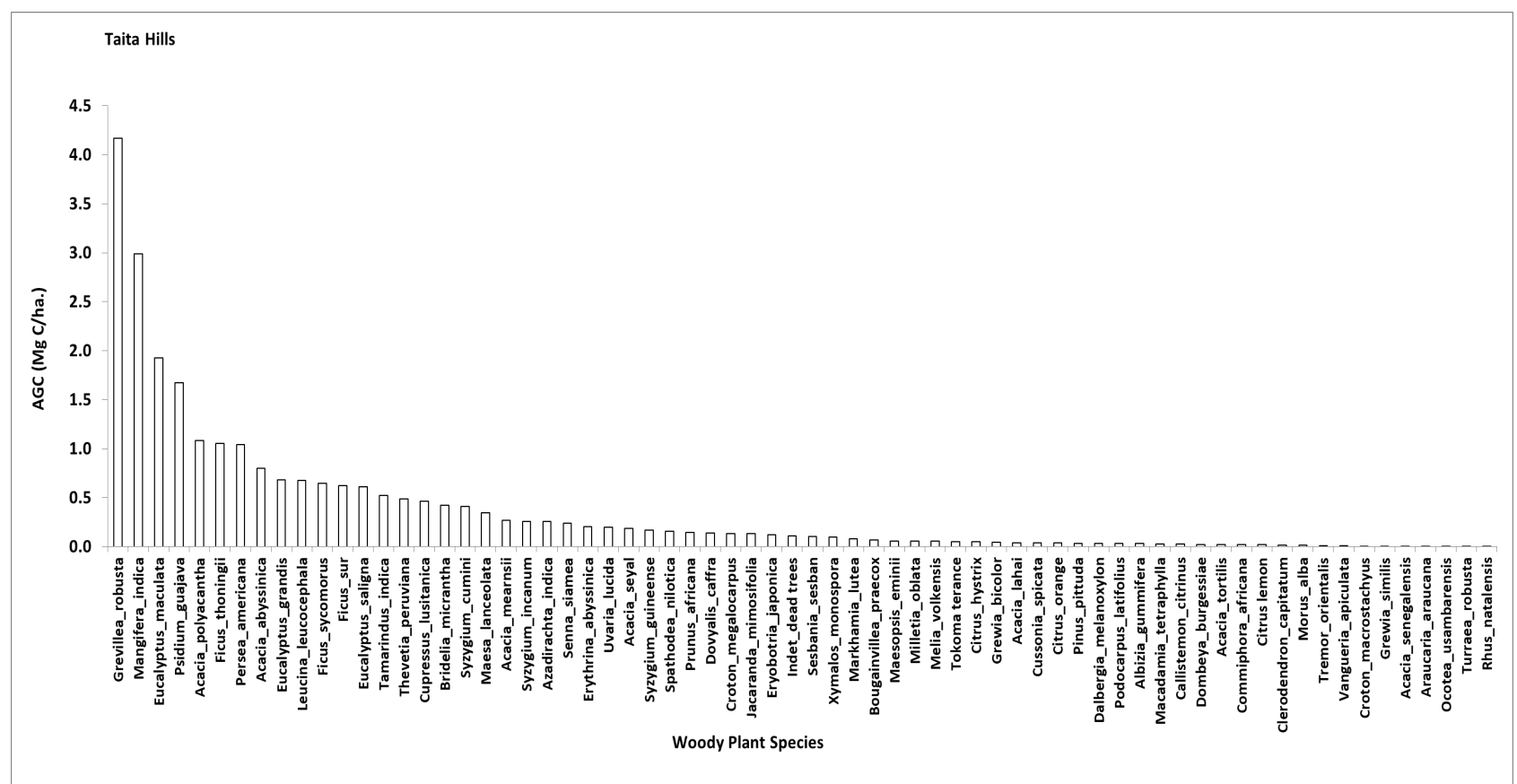

(b)

Figure 4. (a) The distribution of AGC among the Woody Plant Species on the inhabited slopes of Mount Kilimanjaro; (b) The distribution of AGC among the Woody Plant Species on the inhabited slopes of Taita Hills.

indica $(2.6 \mathrm{MgC} / \mathrm{ha}$ ), and; Eucalyptus maculata with $1.7 \mathrm{MgC} / \mathrm{ha}$ (Figure 4(b)). A. gummifera has the highest AGC in agroforestry on Kilimanjaro with 7.7 MgC/ha; while on the Taita Hills, G. robusta predominated with an AGC of $7.6 \mathrm{MgC} / \mathrm{ha}$. AGC on cropped land on the slope of Mount Kilimanjaro and the Taita Hills is predominated by $M$. indica with an estimated AGC of $3.2 \mathrm{MgC} / \mathrm{ha}$ and $2.3 \mathrm{MgC} / \mathrm{ha}$, in respective sites. The distribution of AGC among the Woody 
Plant Species between Mount Kilimanjaro and the Taita Hills was significantly varied ( $\mathrm{p}=0.00, \mathrm{~F}=2.92$ ); while, their mean was not significantly different.

The AGC increases with the increase in woody plant species richness and stock density on both Mount Kilimanjaro and the Taita Hills slopes. The increase of square root of AGC in Mount Kilimanjaro is more varied with the increase in woody species richness hence no significant relationship observed $(\mathrm{F}=$ $2.25, \mathrm{R}^{2}=0.10, \mathrm{p}=0.17$ ) (Figure $5(\mathrm{a})$ ). The square root of AGC increases significantly with the increase in stock density of the woody species in Kilimanjaro $\left(\mathrm{F}=7.81, \mathrm{R}^{2}=0.44, \mathrm{p}=0.02\right)$ (Figure 5(a)). However, assessment of the relationship of stock density and woody species richness in Kilimanjaro indicate an estimated $77 \%$ correlation.

AGC increases significantly with the increase in woody species richness $(\mathrm{F}=$ $\left.15.62, \mathrm{R}^{2}=0.66, \mathrm{p}=0.00\right)$ and stock density $\left(\mathrm{F}=20.19, \mathrm{R}^{2}=0.72, \mathrm{p}=0.00\right)$ on the slopes of the Taita Hills (Figure 5(b)). Earlier analysis of the woody species
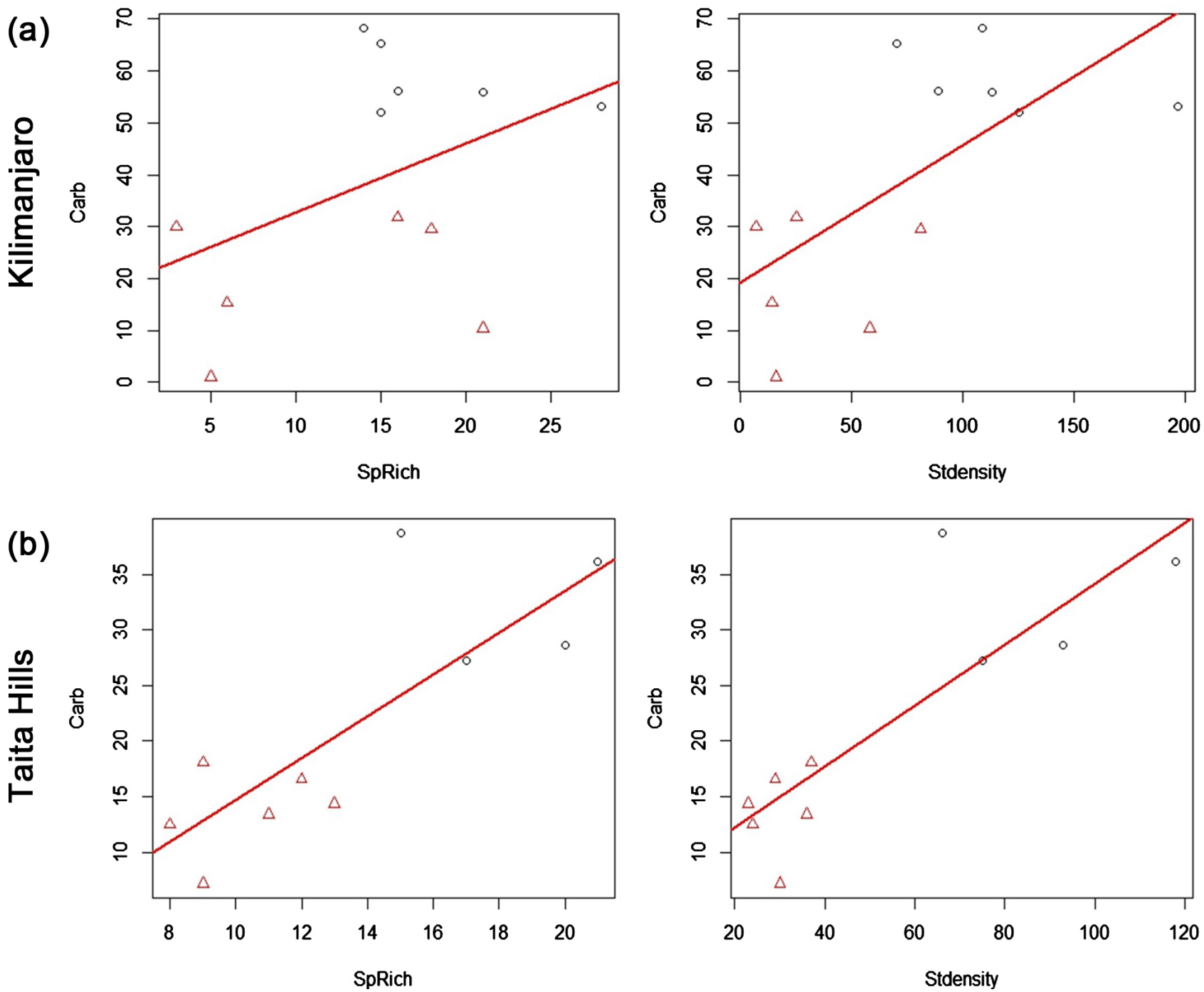

Figure 5. The relationship of AGC (Carb) with the species richness (SpRich) and stock density (abundance); (a) on the slope of Mount Kilimanjaro; (b) on the slopes of the Taita Hills. 
stock density and species richness for the Taita Hills shows the two variables significantly and highly correlated $\left(R^{2}=0.95, F=89.93, p=0.00\right)$.

\subsection{AGC Prediction Models along Elevation Gradients}

The relationship of AGC with environmental variables was explored under univariate and multivariate model relationships. The influence of environmental variables on AGC distribution varies on the inhabited slopes of Mount Kilimanjaro and the Taita Hills. At both sites, AGC increases with the increase in elevation, slope, and edaphic variables (CEC and SOC) EVI and population density, while, AGC decreases with the decrease in edaphic variables such as soil $\mathrm{pH}$ and BLD. However, difference could be observed on the level of significance of the relationship. Variation in elevation gradient is significantly attributed to $72 \%$ of AGC variation in Kilimanjaro $(\mathrm{p}=0.00)$ but no significant relationship was observed in the Taita Hills. The variation of slope angle is significantly linked to about $73 \%$ of AGC distribution in the Taita Hills but not on Kilimanjaro (Table 4). The transect in the inhabited areas of Mount Kilimanjaro has a more or less continuous elevation gradients but the Taita Hills is more interrupted forming steep areas (high slope angles). The inhabited elevation of Mount Kilimanjaro has home gardens observed established towards the middle of the transect increasing in cover towards the end of transect. Less steep areas of the Taita Hills are dominated by annual crop cultivation but as the slope angle increases and land become steeper, the areas are preserved with natural vegetation and/or planted trees.

In particular, the variation of AGC with SOC indicates significant relationships in both Kilimanjaro $\left(\mathrm{R}^{2}=0.72, \mathrm{p}=0.00\right)$ and the Taita Hills $\left(\mathrm{R}^{2}=0.56, \mathrm{p}=\right.$ 0.01) (Figure 6, Table 4). In Kilimanjaro, AGC relates significantly with Soil BLD $\left(\mathrm{R}^{2}=0.72, \mathrm{p}=0.00\right)$ and $\mathrm{pH}\left(\mathrm{R}^{2}=0.80, \mathrm{p}=0.00\right)$ but not in the Taita Hills (Figure 6, Table 4). While, AGC does not relate significantly with CEC in both inhabited slopes of Mount Kilimanjaro and the Taita Hills. Increase of AGC is significant with the increase of EVI on the inhabited slopes of Mount Kilimanjaro $\left(R^{2}=0.68, p=0.00\right)$ and the Taita Hills $\left(R^{2}=0.41, p=0.05\right)$. Population density apparently significantly affects AGC distribution only in the Taita Hills $\left(\mathrm{R}^{2}=0.42, \mathrm{p}=0.04\right)$ but not on the slopes of Mount Kilimanjaro (Figure 6, Table 4).

The multivariate response of AGC to elevation and slope showed significant relationship in Kilimanjaro (KCarbMod1) $\left(\mathrm{R}^{2}=0.72, \mathrm{p}=0.00\right)$ and the Taita Hills (TCarbMod 1$)\left(R^{2}=0.73, p=0.01\right)$ (Table 4). However, multivariate response of AGC to these environmental variables is relatively similar to the univariate response to the elevation in Kilimanjaro and to the slope angle in the Taita Hills. When quadratic function is introduced on the elevation in KCarbMod1 (thus, KCarbMod2) in Kilimanjaro, the response of AGC is increased significantly to about $84 \%$ (Table 4). In the case for the Taita Hills, response of AGC increased significantly but with a small margin. However, when population 
(a) Kilimanjaro
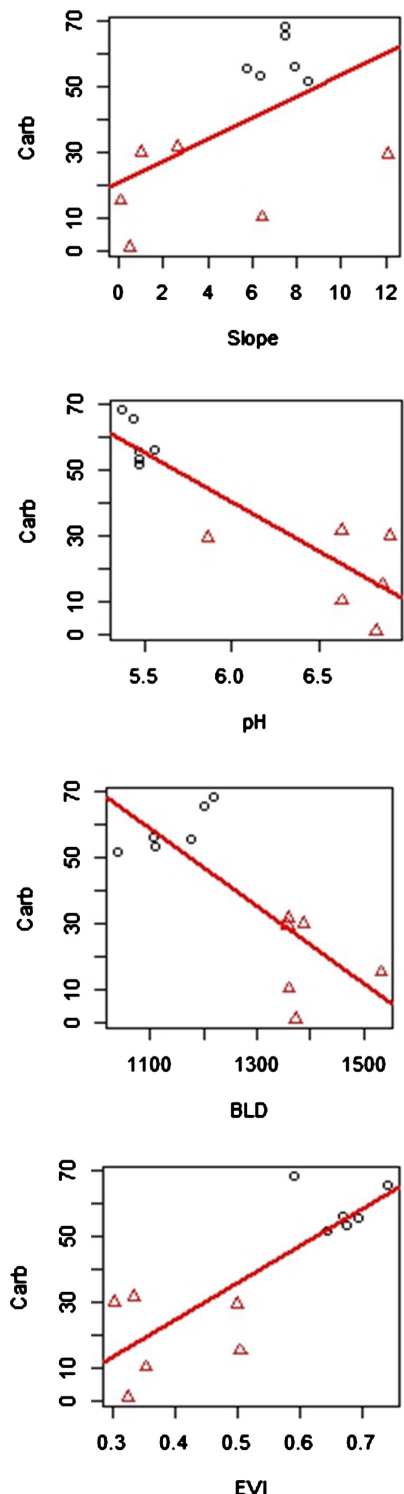

(b) Taita Hills
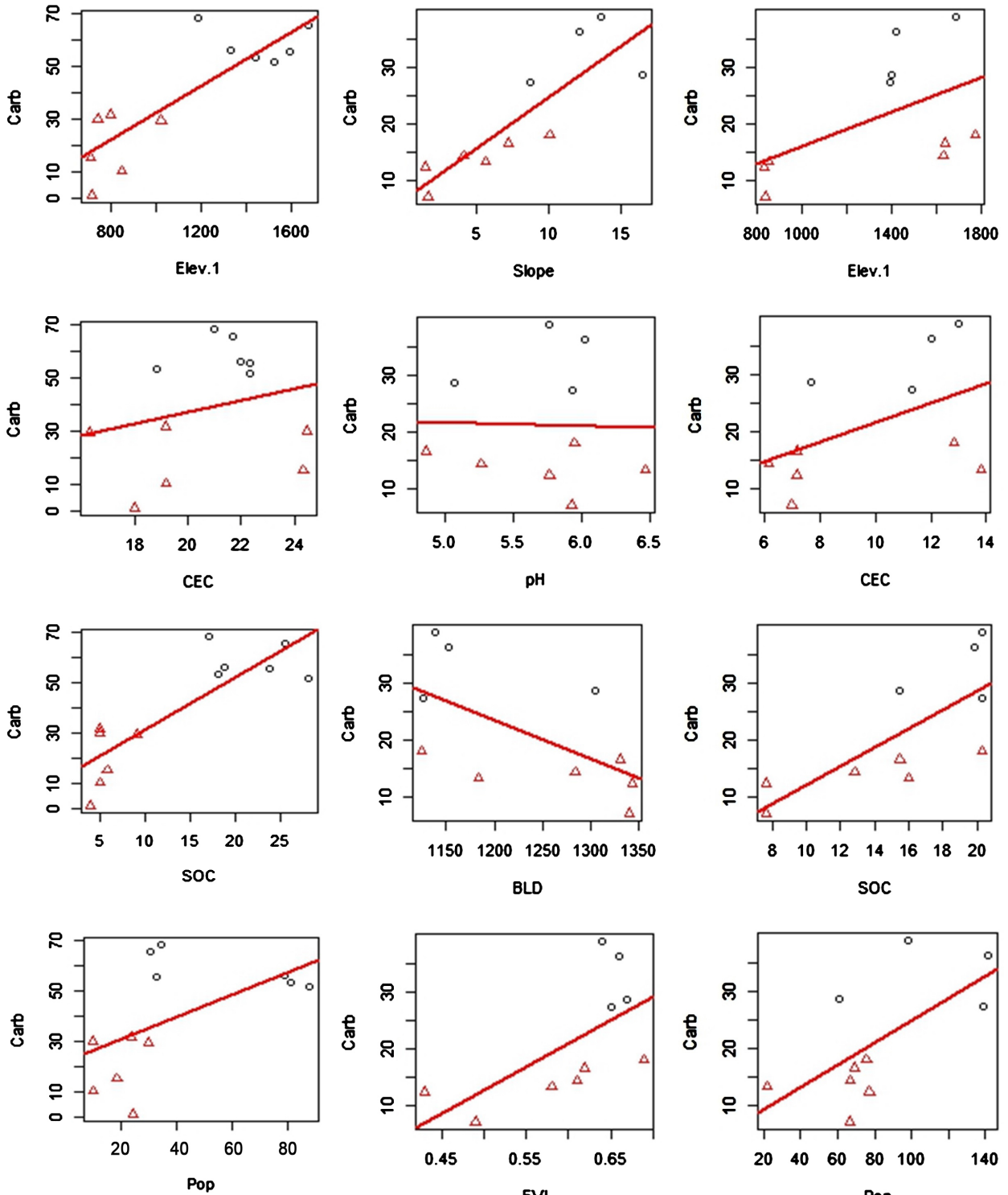

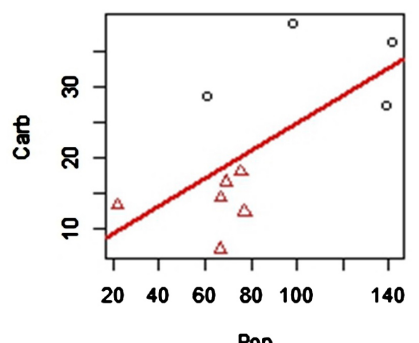

Pop

Figure 6. Relationship of AGC with environmental variables (physical and soil variables) on the inhabited slopes of Mount Kilimanjaro and the Taita Hills.

density is added to the model TCarbMod1 (thus, TCarbMod3), the response of AGC increases significantly to about $89 \%(\mathrm{p}=0.00)$. This implies, other than the slope which seems to be the most important variable influencing AGC in the Taita Hills, population density has effect on the distribution of AGC to an extent. AGC response to the inclusion of population density in KCarbMod1 is not significant. AGC multivariate response to edaphic variables $(\mathrm{pH}, \mathrm{CEC}, \mathrm{BLD}$ and SOC) (KCarbMod3) is very significant $\left(\mathrm{R}^{2}=0.90, \mathrm{p}=0.00\right)$ on Kilimanjaro but not in the Taita Hills (Table 4). The combination of KCarbMod1 with KCarbMod3/7; thus KCarbMod4 (Table 4) shows AGC responds significantly $\left(\mathrm{R}^{2}=\right.$ $0.94, p=0.03$ ) on Kilimanjaro but not in the Taita Hills. However, response of AGC to KCarbMod4 is relatively similar to the response to KCarbMod3. 
Table 4. Prediction, univariate and multivariate model relationship of the Above Ground Carbon Storage (AGC/Carb) with environmental variables on the inhabited slopes of Kilimanjaro and Taita Hills.

\begin{tabular}{|c|c|c|c|c|c|c|c|c|}
\hline Site & & Models & RSE & $\mathrm{DF}$ & Mult. $\mathrm{R}^{2}$ & $\mathrm{~F}$ & $\mathrm{p}$-value & AIC \\
\hline \multirow[t]{12}{*}{ Taita Hills } & Univariate & TCarbMod_Elev $<-\operatorname{lm}($ Carb Elev $)$ & 0.27 & 8 & 0.27 & 2.94 & 0.13 & 77.61 \\
\hline & & TCarbMod_Slope $<-\operatorname{lm}$ (Carb Slope $)$ & 5.94 & 8 & 0.73 & 21.27 & 0.00 & 67.77 \\
\hline & & TCarbMod_pH $<-\operatorname{lm}($ Carb $\sim \mathrm{pH})$ & 11.35 & 8 & 0.00 & 0.01 & 0.95 & 80.73 \\
\hline & & TCarbMod_SOC $<-\operatorname{lm}($ Carb $\sim S O C)$ & 7.53 & 8 & 0.56 & 10.18 & 0.01 & 72.53 \\
\hline & & TCarbMod_CEC $<-\operatorname{lm}($ Carb $\sim$ CEC $)$ & 9.95 & 8 & 0.23 & 2.43 & 0.16 & 78.09 \\
\hline & & TCarbMod_BLD $<-\operatorname{lm}($ Carb $\sim$ BLD $)$ & 9.08 & 8 & 0.36 & 4.49 & 0.07 & 76.28 \\
\hline & & TCarbMod_Pop $<-\operatorname{lm}($ Carb Pop) & 8.64 & 8 & 0.42 & 5.83 & 0.04 & 75.27 \\
\hline & & TCarbMod_EVI $<-\operatorname{lm}($ Carb $\sim E V I)$ & 8.71 & 8 & 0.41 & 5.59 & 0.05 & 75.44 \\
\hline & Multivariate & TCarbMod $1<-\operatorname{lm}($ Carb $\sim$ Elev + Slope $)$ & 6.34 & 7 & 0.73 & 9.32 & 0.01 & 69.75 \\
\hline & & TCarbMod $2<-\operatorname{lm}\left(\right.$ Carb Elev $+\mathrm{I}\left(\mathrm{Elev}^{2}\right)+$ Slope $)$ & 6.49 & 6 & 0.76 & 6.15 & 0.03 & 70.69 \\
\hline & & TCarbMod3 $<-\operatorname{lm}($ Carb $\sim$ Elev + Slope + Pop $)$ & 4.36 & 6 & 0.89 & 16.12 & 0.00 & 62.70 \\
\hline & & $\begin{aligned} \text { TCarbMod5 }< & -\operatorname{lm}\left(\text { Carb Elev }+\mathrm{I}\left(\mathrm{Elev}^{2}\right)+\right. \\
& \text { Slope }+ \text { Pop })\end{aligned}$ & 4.70 & 5 & 0.89 & 10.41 & 0.01 & 64.41 \\
\hline \multirow[t]{12}{*}{ Kilimanjaro } & Univariate & KCarbMod_Elev $<-\operatorname{lm}($ Carb Elev $)$ & 12.54 & 10 & 0.72 & 25.24 & 0.00 & 98.56 \\
\hline & & KCarbMod_Slope $<-\operatorname{lm}$ (Carb Slope $)$ & 19.76 & 10 & 0.30 & 4.20 & 0.07 & 109.47 \\
\hline & & KCarbMod_EVI $<-\operatorname{lm}($ Carb $\sim E V I)$ & 13.32 & 10 & 0.68 & 21.27 & 0.00 & 100.00 \\
\hline & & KCarbMod_pH $<-\operatorname{lm}($ Carb $\sim \mathrm{pH})$ & 10.62 & 10 & 0.80 & 39.14 & 0.00 & 94.58 \\
\hline & & KCarbMod_SOC $<-\operatorname{lm}($ Carb $\sim S O C)$ & 12.44 & 10 & 0.72 & 25.82 & 0.00 & 98.37 \\
\hline & & KCarbMod_CEC $<-\operatorname{lm}($ Carb $\sim$ CEC $)$ & 22.78 & 10 & 0.06 & 0.68 & 0.43 & 112.9 \\
\hline & & KCarbMod_BLD $<-\operatorname{lm}($ Carb BLD $)$ & 14.90 & 10 & 0.60 & 14.97 & 0.00 & 102.7 \\
\hline & & KCarbMod_Pop $<-\operatorname{lm}($ Carb Pop $)$ & 19.67 & 10 & 0.30 & 4.33 & 0.06 & 109.36 \\
\hline & Multivariate & KCarbMod $1<-\operatorname{lm}($ Carb Elev + Slope $)$ & 13.2 & 9 & 0.72 & 11.41 & 0.00 & 100.53 \\
\hline & & KCarbMod $2<-\operatorname{lm}\left(\right.$ Carb Elev $+\mathrm{I}\left(\mathrm{Elev}^{2}\right)+$ Slope $)$ & 10.60 & 8 & 0.84 & 13.77 & 0.00 & 98.05 \\
\hline & & KCarbMod3 $<-\operatorname{lm}($ Carb $\sim \mathrm{SOC}+\mathrm{CEC}+\mathrm{pH}+\mathrm{BLD})$ & 8.79 & 7 & 0.90 & 16.19 & 0.00 & 91.75 \\
\hline & & $\begin{array}{c}\text { KCarbMod } 4<-\operatorname{lm}(\text { Carb } \sim \mathrm{SOC}+\mathrm{CEC}+\mathrm{pH}+\mathrm{BLD}+ \\
\left.\text { Elev. } 1+\mathrm{I}\left(\text { Elev. } 1^{2}\right)+\text { Slope }\right)\end{array}$ & 9.35 & 4 & 0.94 & 8.50 & 0.03 & 92.51 \\
\hline
\end{tabular}

\subsection{Statistical and Visual Validation of AGC Prediction Model}

The evaluation considers models that show significant relationship with the distribution of AGC on the inhabited slopes of Mount Kilimanjaro and the Taita Hills. The AIC indicates the model KCarbMod3/7 performs best in explaining the distribution of AGC on Kilimanjaro (AIC $=87.20$ ). AGC predicted by KCarbMod3/7 and AGC recorded in plots significantly associate by $94 \%(\mathrm{R}=$ $0.94, \mathrm{p}=0.00$ ) on Kilimanjaro transect (Table 5). In the Taita Hills, the model TCarbMod3 performs best in explaining the response of AGC $($ AIC $=71.11)$ and apparently associate with the high proportion of AGC recorded on site $(\mathrm{R}=$ $0.79, \mathrm{p}=0.01$ ) than other models (Table 5). This is followed by SOC model 
Table 5. Evaluation of predicted AGC by correlation with the observed plot AGC on the slopes of Mount Kilimanjaro. PredCarb is the predicted AGC and PlotCarb is the observed plot AGC.

\begin{tabular}{|c|c|c|c|c|}
\hline & \multirow{2}{*}{ Model Relationship } & \multicolumn{3}{|c|}{ PredCarb vs PlotCarb } \\
\hline & & $\mathbf{R}$ & p-value & AIC \\
\hline \multirow{8}{*}{ Univariate Model } & KCarbMod_Elev $<-\operatorname{lm}($ Carb Elev $)$ & 0.83 & 0.00 & 99.79 \\
\hline & KCarbMod_pH $<-\operatorname{lm}($ Carb $\sim \mathrm{pH})$ & 0.90 & 0.00 & 94.29 \\
\hline & KCarbMod_BLD $<-\operatorname{lm}($ Carb $\sim$ BLD $)$ & 0.79 & 0.00 & 102.21 \\
\hline & KCarbMod_SOC $<-\operatorname{lm}($ Carb SOC $)$ & 0.86 & 0.00 & 97.42 \\
\hline & KCarbMod_EVI $<-\operatorname{lm}($ Carb EVI $)$ & 0.86 & 0.00 & 97.51 \\
\hline & TCarbMod_Slope $<-\operatorname{lm}$ (Carb Slope) & 0.57 & 0.10 & 77.04 \\
\hline & TCarbMod_SOC $<-\operatorname{lm}($ Carb $\sim S O C)$ & 0.77 & 0.01 & 71.58 \\
\hline & TCarbMod_EVI $<-\operatorname{lm}($ Carb EVI $)$ & 0.67 & 0.03 & 74.79 \\
\hline \multirow{9}{*}{$\begin{array}{c}\text { Multivariate } \\
\text { Model }\end{array}$} & TCarbMod_Pop $<-\operatorname{lm}$ (Carb Pop) & 0.05 & 0.89 & 80.71 \\
\hline & KCarbMod $1<-\operatorname{lm}($ Carb Elev + Slope $)$ & 0.83 & 0.00 & 99.60 \\
\hline & KCarbMod $2<-\operatorname{lm}\left(\right.$ Carb Elev $+\mathrm{I}\left(\mathrm{Elev}^{2}\right)+$ Slope $)$ & 0.83 & 0.00 & 99.87 \\
\hline & KCarbMod3/7 $<-\operatorname{lm}($ Carb $\sim \mathrm{SOC}+\mathrm{CEC}+\mathrm{pH}+\mathrm{BLD})$ & 0.94 & 0.00 & 87.20 \\
\hline & KCarbMod4 $/ 12<-\operatorname{lm}\left(\right.$ Carb $\sim$ SOC + CEC + pH + BLD + Elev. $1+$ I(Elev. $\left.1^{2}\right)+$ Slope $)$ & 0.92 & 0.00 & 91.33 \\
\hline & TCarbMod $1<-\operatorname{lm}($ Carb $\sim$ Elev + Slope $)$ & 0.56 & 0.09 & 77.00 \\
\hline & TCarbMod $2<-\operatorname{lm}\left(\right.$ Carb $\sim$ Elev $+\mathrm{I}\left(\mathrm{Elev}^{2}\right)+$ Slope $)$ & 0.64 & 0.05 & 75.49 \\
\hline & TCarbMod $3<-\operatorname{lm}($ Carb $\sim$ Elev + Slope + Pop $)$ & 0.79 & 0.01 & 71.11 \\
\hline & TCarbMod5 $<-\operatorname{lm}\left(\right.$ Carb $\sim$ Elev $+\mathrm{I}\left(\mathrm{Elev}^{2}\right)+$ Slope + Pop $)$ & 0.13 & 0.73 & 80.57 \\
\hline
\end{tabular}

(AIC $=71.58)$ with the predicted AGC correlates with 77\% of AGC recorded on plots frim the Taita Hills ( $\mathrm{R}=0.77, \mathrm{p}=0.01)$ (Table 5).

The visual inspections of spatial models generated from the statistical models (univariate and multivariate) tend to validate some of the AGC univariate and multivariate response. Most of the spatially predicted AGC shows poor prediction on the lower elevations of the transect on the inhabited slopes on Mount Kilimanjaro. The predicted AGC values are visually incomparable with the plot AGC values in the lower elevation except for $\mathrm{pH}$ model. Some of the models such as univariate elevation, $\mathrm{pH}$ and EVI tend to generate spatial AGC that compares with the values of plot AGC in the upper elevation. The univariate $\mathrm{pH}$ and EVI apparently performs better in spatially predicting AGC on the slopes of Mount Kilimanjaro.

Spatially predicted AGC in the Taita Hills by the univariate TCarbMod_SOC and multivariate model consisting of elevation, slope and population (TCarbMod3) has visually comparable spatial model (Figure 7, Table 5). Spatial prediction of AGC by TCarbMod_EVI has close visual pattern of AGC distribution with TCarbMod_SOC and TCarbMod3. The spatial AGC model from univariate 

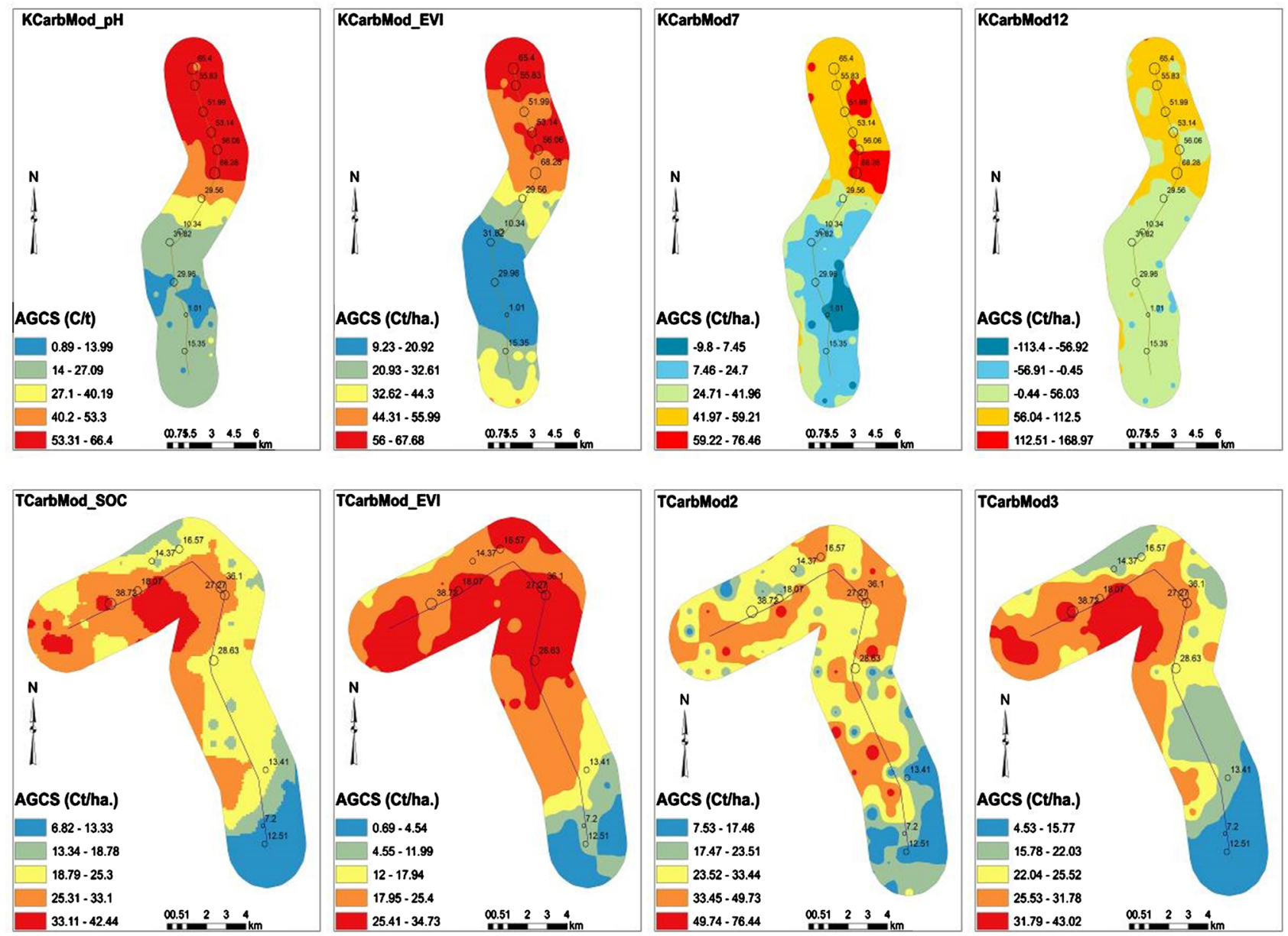

Figure 7. Spatial model prediction of aboveground carbon storage AGCS based on the univariate and multivariate models for Mount Kilimanjaro and the Taita Hills. Prefix T refers to the Taita Hills and K is Kilimanjaro. CarbMod refers to Carbon Model. The univariate models have variable identity at the end; for example slope (TCarbMod_Slope). The multivariate models include KCarbMod3/7 (SOC + CEC + pH + BLD), and KCarbMod4/12 (SOC + CEC + pH + BLD + Elevation + I (Elevation $\left.{ }^{2}\right)+$ Slope $)$. The multivariate models for Taita include: TCarbMod2 (Elevation + I(Elevation $\left.{ }^{2}\right)+$ Slope), TCarbMod3 (Elevation + Slope + Population density).

slope, TCarbMod 1 and TCarbMod 2 are also comparable visually and this could probably be because they have slope as a factor in the multivariate models (Figure 7, Table 5). However, models TCarbMod_SOC, TCarbMod_EVI and TCarbMod3 (Figure 7, Table 5) has predicted AGC values and observed plot AGC comparable which makes them better models for predicting AGC spatial on the inhabited slopes of the Taita Hills.

\section{Discussion}

Carbon storage in the aboveground living biomass of trees forms the largest pool and the most directly impacted by deforestation and degradation [44]. Tropical montane forests have in the last centuries and decades been converted to other land uses or degraded [45]. Cropland established on previously sparsely vegetated or highly disturbed lands can result in a net gain in both biomass and soil carbon [46]. Permanent cropland is considered to be a broad category that con- 
sists of cropped land, agroforestry and rice paddies [1]. Cropped land consists of the annual crops and or mono-cropping systems; while, agroforestry is characterized by mixed annual and perennial crops with fruit trees and trees of socio-economic benefits in the background. One of the key issues addressed in this study concerns the above-ground carbon stored in different types of cropped lands and agroforestry systems along the densely inhabited slopes of Mount Kilimanjaro and the Taita Hills.

The inhabited montane area of Mount Kilimanjaro has $39.06 \pm 6.48 \mathrm{Mg} \mathrm{C} \mathrm{ha}^{-1}$ and the Taita Hills $28.82 \pm 5.82 \mathrm{Mg} \mathrm{C} \mathrm{ha}^{-1}$ occurring within the mean range of AGC in East Africa ranging between $0.6 \mathrm{Mg} \mathrm{C} \mathrm{ha}^{-1}$ in permanent cropland [9] to 91.5 Mg C ha ${ }^{-1}$ in agroforestry system [20]. A recent study in the Taita Hills suggest cropland has an average of $9.1 \mathrm{Mg} \mathrm{Cha}^{-1}$ in areas above $1220 \mathrm{~m}$ a.s.l. and 2.3 $\mathrm{Mg} \mathrm{C} \mathrm{ha}^{-1}$ below $1220 \mathrm{~m}$ a.s.l. which is considerably lower than our result [7]. Agroforestry areas have higher amounts of mean AGC with Kilimanjaro storing higher amount of AGC $\left(58.45 \pm 2.75 \mathrm{Mg} \mathrm{C} \mathrm{ha}^{-1}\right)$ than the Taita Hills $\left(31.98 \pm 7.40 \mathrm{Mg} \mathrm{C} \mathrm{ha}^{-1}\right)$. This is certainly higher than the amount of carbon indicated for different types of agroforestry [46]. On the other hand, cropped lands in Kilimanjaro have AGC of $19.67 \pm 5.18 \mathrm{Mg} \mathrm{C}^{-1}$ and then Taita Hills cropped lands estimated at $13.69 \pm 1.54 \mathrm{Mg} \mathrm{C} \mathrm{ha}^{-1}$. AGC in the two sites are higher than the amount of AGC estimated in most cropland in East Africa between 1.6 to $4.8 \mathrm{Mg} \mathrm{C} \mathrm{ha}^{-1}$ [21] and the amounts of carbon storage in sub-humid and semi-arid ecoregions [47]. However, AGC in the woodlots in the cropland areas range from 39.4 to $123 \mathrm{Mg} \mathrm{C} \mathrm{ha}^{-1}$ [9] which is higher than AGC in ordinary agroforestry areas. Pellikka et al. [7] found increase in carbon stocks in croplands over $1200 \mathrm{~m}$.

AGC in cropped lands on Kilimanjaro and the Taita Hills is lower than agroforestry values it is higher than in other croplands in the region. The amount of AGC in cropped land and agroforestry areas on the slopes of Mount Kilimanjaro differ significantly in their means and variation, while in the Taita Hills significant difference was only observed on the variation. This difference could be brought about by the high amount of AGC in the agroforestry trees and some indigenous trees retained when forest in montane areas is converted into cropland [46]. The difference in AGC in cropped land and agroforestry areas in the two sites also depends on the crop type, management practices, and soil and climate variables in the croplands [48]. Cropped lands consist of treeless monocrop stand with few trees on hedges; while, agroforestry systems are characterized by vegetation structure that falls below the thresholds used for the Intergovernmental Panel on Climate Change Forest Land Category [2].

In this study, AGC is not only compared between sites but also analyzed against elevation gradients within each and between the sites. Most studies indicate the above-ground biomass and carbon stock significantly decreases with the increase in elevation [38]; and varies strongly between and within continents [47]. Elevational gradient causes great variation in vegetation structure and car- 
bon stock among sites [26] [41] [28]. For instance, in short elevational gradients ( $<2000 \mathrm{~m}$ a.s.1.), as in the case of the Taita Hills, vegetation zones are more compressed and edaphic discontinuities stronger in short distance due to steep topography and microclimate variation than in long elevational gradients $(>2000 \mathrm{~m}$ a.s.l.) [26]. Due to variation of morpho-species of woody plant species with elevation gradient in site, about $59 \%$ of AGC significantly varies with the woody plant species in Ipeti'-Embera' in eastern Panama Province, Panama [49]. Similarly this relationship is observed on the slopes of the Taita Hills where about $66 \%$ of AGC is explained significantly by the distribution of the woody plant species richness along elevation gradients. This relationship is absent on the slopes of Mount Kilimanjaro probably because of the predominance of banana plantation for shading coffee. Even though AGC distribution is affected differently by elevation gradients and slope angle on Kilimanjaro and the Taita Hills, similar study in Udzungwa and Usambara confirms significant influence of slope angle and elevation on AGC [38].

Climate (precipitation and temperature) and soil factors vary with elevation gradients [41] [42]. Through this interaction, elevation gradients intercorrelate with the climate and soil variables depending on the type of elevation gradient. AGC varies significantly with variation of soil $\mathrm{pH}, \mathrm{BLD}$ and SOC on the slopes of Mount Kilimanjaro while AGC does not vary with the edaphic variables in the Taita Hills. However, population density seems to associate with about $42 \%$ of AGC distribution on the slopes of the Taita Hills. Evaluation of univariate and multivariate models statistically and spatially show that soil $\mathrm{pH}$ is the strongest and most significant predictor for AGC by $80 \%$ on the slopes of Mount Kilimanjaro, while in the Taita Hills, three variables (elevation, slope and population density) simultaneously affect the distribution of AGC on the inhabited slopes of the area.

The analysis of this work depended on secondary remotely sensed environmental variables at a resolution of $0.5-1 \mathrm{~km}$. This resolution might have not been sensitive to variation of soil and climate factors that could change drastically within a short distance on the inhabited slopes of Mountain areas. In order to minimize errors that could emerge from generalization of environmental variables at this resolution, sampling points more than $1 \mathrm{~km}$ apart were considered in the analysis. This implies the numbers of sampling points were reduced and this together with the secondary environmental variables would potentially affect precision of the results. Variation in the average amount of carbon storage between this study and others can also be impacted on by sampling designs adopted by different researchers. Thus, future consideration of standardized field measurements of environmental variables and increasing the number of sample size would improve the results.

This research has wider application in understanding the drivers behind carbon storage, within agroforestry systems, biodiversity conservation and water conservation on the inhabited slopes of Mount Kilimanjaro and the Taita Hills. 
Water balance is a variable which is affected by carbon storage (AGC and SOC) and should be a consideration in the water conservation policy and management of montane forest systems as a key hydrological resource [50]. Understanding factors that relate with the AGC at a local scale provide an efficient means of monitoring AGC in a large area of study for future conservation and for enhancing the management of agroforestry systems. Information on AGC on the inhabited slopes provide baseline for future assessment of carbon emissions through removal of the woody plants and loss of soil organic carbon through land degradation. Management of carbon sequestration within densely inhabited landscapes can be adopted through agroforestry development such as the careful selection of tree species that are preferred at a local site by local communities and have good storage potential. The study shows that most of the AGC is contributed by agroforestry exotic tree species but indigenous species constitute low percentage which potentially affects biodiversity conservation. Consideration of indigenous tree species in agroforestry policy will bring about a balance between biodiversity conservation and socio-economic of the local communities on the inhabited slopes of Mount Kilimanjaro and the Taita Hills.

\section{Conclusion}

The inhabited slopes of Mount Kilimanjaro and the Taita Hills have relatively similar amounts of AGC. Along the study transects the AGC varies significantly within different cropped land and agroforestry systems. The two sites differ on the predominant woody tree species that contribute more AGC on the inhabited slopes; A. gummifera and G. robusta contribute more to AGC on Mount Kilimanjaro and the Taita Hills, respectively. The elevation gradient significantly explains the distribution of AGC on slopes of Mount Kilimanjaro but slope angle seems to be significant on the slope of the Taita Hills. Most of soil variables explain significant variation of AGC on the slopes of Mount Kilimanjaro more than in the Taita Hills. However, SOC and EVI significantly explain the distribution of AGC on both sites but not so strongly in the Taita Hills. AGC distribution is significantly explained by multiple effects of elevation and slope angle on the slopes of the two sites. Population density together with elevation and slope angle apparently affect distribution of AGC in the Taita Hills but not on Kilimanjaro. Significant multiple effect of soil variables ( $\mathrm{pH}, \mathrm{CEC}, \mathrm{BLD}$ and $\mathrm{SOC}$ ) is only observed on the slopes of Mount Kilimanjaro. AGC distribution on the slopes of Mount Kilimanjaro can be predicted by univariate $\mathrm{pH}$ and EVI models. In the Taita Hills, univariate SOC, EVI models and multivariate model of elevation, slope and population predict AGC reliably. These insights on the factors that control AGC in mountain agroforestry system are keies to informing management that aims to strike a balance between biodiversity conservation and socio-economic livelihoods on the densely inhabited slopes of Mount Kilimanjaro and the Taita Hills; insights that are relevant more widely to other mountain ecosystems and communities. 


\section{Acknowledgements}

This research was carried out within CHIESA project coordinated by International Centre of Insect Physiology and Ecology (Icipe) funded by Ministry for Foreign Affairs of Finland. PP acknowledges Finnish Culture Foundation funding project remote sensing of water harvesting and carbon sequestration by forests in the Taita Hills, Kenya and Academy of Finland funding TAITAWATER (integrated land cover-climate-ecosystem process study for water management in East African highlands). Taita Research Station of the University of Helsinki in the Taita Hills is acknowledged for logistical support. The York Institute for Tropical Ecosystem (KITE) provided resources and support for staying at York city during data analysis. I'm grateful to the National Museums of Kenya and the University of Nairobi for their immense in-kind support during the fieldwork and development of the manuscript. Research permit NCST/RCD/17/012/33 for Taita Research Station from National Council for Science and Technology of Kenya is greatly acknowledged.

\section{Conflicts of Interest}

The authors declare no conflicts of interest regarding the publication of this paper.

\section{References}

[1] Inter-Governmental Panel on Climate Change (2006) IPCC Guidelines for National Greenhouse Gas Inventories.

[2] Hairiah, K., Dewi, S., Agus, F., Velarde, S., Ekadinata, A., Rahayu, S. and van Noordwijk, M. (2011) Measuring Carbon Stocks across Land Use Systems: A Manual. World Agroforestry Center (ICRAF), SEA Regional Office, Bogor, 154 p.

[3] Sanchez, P.A. (1995) Science in Agroforestry. Agroforestry Systems, 30, 5-55. https://doi.org/10.1007/BF00708912

[4] Leakey, R.R.B. (1996) Definition of Agroforestry Revisited. Agroforestry Today, 8, $5-7$.

[5] Landmann, T. and Dubovyk, O. (2014) Spatial Analysis of Human-Induced Vegetation Productivity Decline over Eastern Africa Using a Decade (2001-2011) of Medium Resolution MODIS Time-Series Data. International Journal of Applied Earth Observation and Geoinformation, 33, 76-82. https://doi.org/10.1016/j.jag.2014.04.020

[6] Aerts, R., Thijs, K., Lehouck, V., Beentje, H., Bytebier, B., Matthysen, E., et al. (2011) Woody Plant Communities of Isolated Afromontane Cloud Forests in Taita Hills, Kenya. Plant Ecology, 212, 639-649. https://doi.org/10.1007/s11258-010-9853-3

[7] Pellikka, P.K.E., Heikinheimo, V., Hietanen, J., Schafer, E., Siljander, M. and Heiskanen, J. (2018) Impact of Land Cover Change on Aboveground Carbon Stocks in Afromontane Landscape in Kenya. Applied Geography, 94, 178-189. https://doi.org/10.1016/j.apgeog.2018.03.017

[8] Denu, D., Platts, P.J., Kelbessa, E., Gole T.W. and Marchant, R. (2016) The Role of Traditional Coffee Management in Forest Conservation and Carbon Storage in the 
Jimma Highlands, Ethiopia. Forest, Trees and Livelihoods, 25, 226-238.

[9] Henry, M., Tittonell, P., Manlay, R.J., Bernou, M., Albrecht, A. and Vanlauwe, B. (2009) Biodiversity, Carbon Stocks and Sequestration Potential in Aboveground Biomass in Smallholder Farming Systems of Western Kenya. Agriculture, Ecosystems and Environment, 129, 238-252. https://doi.org/10.1016/j.agee.2008.09.006

[10] Brink, A.B. and Eva, H.D. (2009) Monitoring 25 Years of Land Cover Change Dynamics in Africa: A Sample Based Remote Sensing Approach. Applied Geography, 29, 501-512. https://doi.org/10.1016/j.apgeog.2008.10.004

[11] Brink, A.B., Bodart, C., Brodsky, L., Defourney, P., Donney, F., et al. (2014) Anthropogenic Pressure in East Africa-Monitoring 20 Years of Land Cover Changes by Means of Medium Resolution Satellite Data. International Journal of Applied Earth Observation and Geoinformation, 28, 60-69. https://doi.org/10.1016/j.jag.2013.11.006

[12] Friedl, M.A., et al. (2002) Global Land Cover Mapping from MODIS: Algorithms and Early Results. Remote Sensing of Environment, 83, 287-302. https://doi.org/10.1016/S0034-4257(02)00078-0

[13] Ramankutty, N. and Foley, J.A. (1999) Estimating Historical Changes in Global Land Cover: Croplands from 1700 to 1992. Global Biogeochemical Cycles, 13, 997-1027. https://doi.org/10.1029/1999GB900046

[14] JRL (Joint Research Laboratory) (2005) GLC 2000 (Global Land Cover) Data Layer. JRL, Ispra.

[15] Doherty, R.M., Sitch, S., Smith, B., Lewis, S.L. and Thomton, P.K. (2010) Implications of Future Climate and Atmospheric $\mathrm{CO}_{2}$ Content for Regional Biogeochemistry, Biogeography and Ecosystem Services across East Africa. Global Change Biology, 16, 617-640. https://doi.org/10.1111/j.1365-2486.2009.01997.x

[16] Pfeifer, M., Gonsamo, A., Disney, M., Pellikka, P. and Marchant, R. (2012) Leaf Area Index for Biomes of the Eastern Arc Mountains: Landsat and SPOT Observations along Precipitation and Altitude Gradients. Remote Sensing of Environment, 118, 103-115. https://doi.org/10.1016/j.rse.2011.11.009

[17] Maeda, E.E., Clark, B.J.F., Pellikka, P. and Siljander, M. (2010) Modelling Agricultural Expansion in Kenya's Eastern Arc Mountains Biodiversity Hotspot. Agricultural Systems, 103, 609-620. https://doi.org/10.1016/j.agsy.2010.07.004

[18] Pellikka, P., Clark, B., Gonsamo, A., Himberg, N., Hurskainen, P., Maeda, E., Mwangombe, J., Omoro, L. and Siljander, M. (2013) Agricultural Expansion and Its Consequences in the Taita Hills, Kenya. Developments in Earth Surface Processes, 33, 165-179. https://doi.org/10.1016/B978-0-444-59559-1.00013-X

[19] Ramankutty, N., Foley, J.A. and Olejniczak, N.J. (2002) People on the Land: Changes in Global Population and Croplands during the 20th Century. Ambio, 31, 251-257. https://doi.org/10.1579/0044-7447-31.3.251

[20] Baccini, A., Laporte, N., Goetz, S.J., Sun, M. and Dong, H. (2008) A First Map of Tropical Africa's Above-Ground Biomass Derived from Satellite Imagery. Environmental Research Letter, 3, Article ID: 045011.

[21] Pfeifer, M., Platts, P.J., Burgess, N., Swetnam, R., Willcock, S. and Marchant, R. (2013) Land Use Change and Carbon Fluxes in East Africa Quantified Using Earth Observation Data and Field Measurements. Environmental Conservation, 40, 241-252. https://doi.org/10.1017/S0376892912000379

[22] Cramer, W.P. and Solomon, A.M. (1993) Climatic Classification and Future Global Redistribution of Agricultural Land. Climate Research, 3, 97-110. 
https://doi.org/10.3354/cr003097

[23] Charles, R.C., Nzunda, E.F. and Munishi, P.K.T. (2014) Agroforestry as a Resilient Strategy in Mitigating Climate Change in Mwanga District, Kilimanjaro, Tanzania. Global Journal of Bilogy, Agriculture and Health Sciences, 3, 11-17.

[24] Marchant, R. (2007) The Importance of the Indian Ocean for Climate Change in East Africa. Ship and Ocean News, 13, 282-284. (In Japanese)

[25] Grubb, P.J. (1977) Control of Forest Growth and Distribution on Wet Tropical Mountains: With Special Reference to Mineral Nutrition. Annual Review of Ecology and Systematics, 8, 83-107. https://doi.org/10.1146/annurev.es.08.110177.000503

[26] Hemp, A. (2006) Continuum or Zonation? Altitudinal Gradients in the Forest Vegetation of Mt. Kilimanjaro. Plant Ecology, 184, 27-42. https://doi.org/10.1007/s11258-005-9049-4

[27] Alves, F.L., Vieira, S.A., Scaranello, M.A., Camargo, P.B., Santos, F.A.M., Joly, C.A. and Martinelli, L.A. (2010) Forest Structure and Alive Aboveground Biomass Variation along an Elevational Gradient of Tropical Moist Forest (Brazil). Forest Ecology and Management, 260, 679-691. https://doi.org/10.1016/j.foreco.2010.05.023

[28] Adhikari, H., Heiskanen, J., Siljander, M., Maeda, E., Heikinheimo, V. and Pellikka, P. (2017) Determinants of Aboveground Biomass across an Afromontane Landscape Mosaic in Kenya. Remote Sensing, 9, 827.

[29] Lovett, J.C. and Wasser, S.K. (2008) Biogeography and Ecology of the Rain Forest of Eastern Africa. Cambridge University Press, Cambridge.

[30] Maeda, E.J., Wiberg, D. and Pellikka, P.K.E. (2011) Estimating Reference Evapotranspiration Using Remote Sensing and Empirical Models in a Region with Limited Ground Data Availability in Kenya. Applied Geography, 31, 251-258. https://doi.org/10.1016/j.apgeog.2010.05.011

[31] Erdogan, E.H., Pellikka, P. and Clark, B. (2011) Impact of Land Cover Change on Soil Loss in the Taita Hills, Kenya between 1987 and 2003. International Journal of Remote Sensing, 32, 5919-5945.

[32] Pellikka, P.K.E., Lötjönen, M., Siljander, M. and Lens, L. (2009) Airborne Remote Sensing of Spatiotemporal Change (1955-2004) in Indigenous and Exotic Forest Cover in the Taita Hills, Kenya. International Journal of Applied Earth Observation and Geoinformation, 11, 221-232. https://doi.org/10.1016/j.jag.2009.02.002

[33] Misana, S.B., Sokoni, C. and Mbonile, M.J. (2012) Land-Use/Cover Changes and Their Drivers on the Slopes of Mount Kilimanjaro, Tanzania. Journal of Geographical and Regional Planning, 5, 151-164.

[34] Philips, O., Baker, T., Feldpausch, T. and Brienen, R. (2009) RAINFOR Field Manual for Plot Establishment and Remeasurement.

[35] Zanne, A.E., Lopez-Gonzalez, G., Coomes, D.A., Ilic J., Jansen, S., Lewis, S.L., Miller, R.B., Swenson, N.G., Wiemann, M.C. and Chave, J. (2009) Data from: Towards a Worldwide Wood Economics Spectrum. Dryad Digital Repository.

[36] Chave, J., Coomes, D.A., Jansen, S., Lewis, S.L., Swenson, N.G. and Zanne, A.E. (2009) Towards a Worldwide Wood Economics Spectrum. Ecology Letters, 12, 351-366. https://doi.org/10.1111/j.1461-0248.2009.01285.x

[37] Chave, J., Rejou-Mechchain, M., Burquez, A., Chidumayo, E., Colgan, M.S., Delitti, W.B.C., Duque, A., Eid, T., Fearnside, P.M., Goodman, R.C., Henry, M., Martinez-Yrizar, A., Mugasha, W.A., Muller-Landau, H.C., Mencuccini, M., Nelson, B.W., Ngomanda, A., Nogueira, E.M., Ortiz-Malavassi, E., Pelissier, R., Ploton, P., Ryan, C.M., Saldarriaga, J.G. and Vieilledent, G. (2014) Improved Allometric Mod- 
els to Estimate the Aboveground Biomass of Tropical Trees. Global Change Biology, 20, 3177-3190. https://doi.org/10.1111/gcb.12629

[38] Marshal, A.R., Willcock, S., Platts, P.J., Lovett, J.C., Balford, A., Burgess, N.D., Latham, J.E., Munishi, P.K.T., Salter, R., Shirima, D.D. and Lewis, S.L. (2012) Measuring and Modeling Above-Ground Carbon and Tree Allometry along a Tropical Elevation Gradient. Biological Conservation, 154, 20-33. https://doi.org/10.1016/j.biocon.2012.03.017

[39] Chave, J., Andalo, C. and Brown, S. (2005) Tree Allometry and Improved Estimation of Carbon Stocks and Balance in Tropical Forests. Oecologia, 145, 87-99. https://doi.org/10.1007/s00442-005-0100-x

[40] Huete, A. and Didan, K. (2006) MODIS Vegetation Index Product Series Collection 5 Change Summary. University of Arizona, Tucson.

[41] Asner, G.P., Hughes, R.F., Varga, T.A., Knapp, D.E. and Bowdoin, T.K. (2009) Environmental and Biotic Controls over Aboveground Biomass throughout a Tropical Rain Forest. Ecosystems, 12, 262-278. https://doi.org/10.1007/s10021-008-9221-5

[42] Muller-Landau, H.C. (2004) Interspecific and Inter-Site Variation in Wood Specific Gravity of Tropical Trees. Biotropica, 36, 32. https://doi.org/10.1111/j.1744-7429.2004.tb00292.x

[43] R Core Team (2013) R: A Language and Environment for Statistical Computing. R Foundation for Statistical Computing, Vienna. http://www.R-project.org/

[44] Willcock, S., Phillips, O.L., Platts, P.J., et al. (2014) Quantifying and Understanding Carbon Storage and Sequestration within the Eastern Arc Mountains of Tanzania, a Tropical Biodiversity Hotspot. Carbon Balance and Management, 9, 2. https://doi.org/10.1186/1750-0680-9-2

[45] Unruh, J.D., Houghton, J. and Lefebvre, P.A. (1993) Carbon Storage in Agroforestry: An Estimate for Sub-Saharan Africa. Climate Research, 3, 39-52. https://doi.org/10.3354/cr003039

[46] Schroeder, P. (1994) Carbon Storage Benefits of Agroforestry Systems. Agroforestry Systems, 27, 89-97. https://doi.org/10.1007/BF00704837

[47] Inter-Governmental Panel on Climate Change (2003) Good Practice Guidance for Land Use, Land-Use Change and Forestry.

[48] Kirby, K.R. and Potvin, C. (2007) Variation in Carbon Storage among Tree Species: Implications for the Management of a Small-Scale Carbon Sink Project. Forest Ecology and Management, 246, 208-221. https://doi.org/10.1016/j.foreco.2007.03.072

[49] Cuni-Sanchez, A., Omeny, P., Pfeifer, M., Olaka, L., Mamo, M.B., Marchant, R. and Burgess, N.D. (2018) Climate Change and Pastoralists: Perceptions and Adaptation in Montane Kenya. Climate and Development. https://doi.org/10.1080/17565529.2018.1454880

[50] Ensslin, A., Rutten, G., Pommer, U., Zimmermann, R., Hemp, A. and Fischer, M. (2015) Effects of Elevation and Land Use on the Biomass of Trees, Shrubs and Herbs at Mount Kilimanjaro. Ecosphere, 6, 45. https://doi.org/10.1890/ES14-00492.1 